\title{
Community Engagement, Personal Responsibility and Self Help in Cuba's Health System Reform
}

\author{
Isabel P. Luis MD MS, Silvia Martínez MD PhD, Adolfo Alvarez MPH
}

\begin{abstract}
In 2011 the Cuban health system began a process of sectoral reform to maintain and improve the health of Cuba's population, in response to new challenges and demands in the health sector and population health status. The main actions involved are reorganization, consolidation and regionalization of services and resources. Although community engagement and personal responsibility are not explicitly mentioned in the strategy document, it is advisable to use this opportunity to revitalize both topics and encourage appropriate and full incorporation into the Cuban health system. Both are consistent with the objectives and actions of system reforms proposed, in that they allow the various social actors to assume shared responsibility in working toward social goals-in this case, health gains.
\end{abstract}

This approach also recognizes that reaching such goals is a collective endeavor, to be pursued according to ethical principles (beneficence as responsibility and justice as solidarity), with community involvement and personal responsibility emerging as two important factors subject to reorientation in the context of the health system reform under way.

KEYWORDS Community action, community participation, self care, self-management, social responsibility, health care reform, Cuba

\section{INTRODUCTION}

Modern health sector reform has four pillars. The first three are equity, sustainability and quality of health services. Quality is achieved through actions aimed at rightsizing, reorganization and improvement of: a) accessibility, continuity, appropriateness, efficiency and effectiveness of services, b) health care timeliness and safety, c) scientific and technical competence of health personnel, and d) population satisfaction with health care.[1,2]

This paper addresses the fourth pillar: community engagement in health, which we will define as the process by which individuals and families assume personal responsibility for individual and collective health and wellbeing, becoming - as they better understand their own health problems and needs-active agents of social and health development when they collaborate in decisionmaking concerning health-related actions.

Personal responsibility for health is the understanding that our actions have consequences for individual and collective health. It implies that, ethically and morally, we have a civic duty to act in daily life in such a way that our behavior is not harmful to our wellbeing or that of our fellow citizens. The ethical foundation of this approach is that a claim to any right should necessarily be accompanied by fulfillment of a duty.[3]

Self help is defined as the various activities of daily life carried out by individuals, families and communities to care for their health, prevent disease and reduce harm.[4]
With this article we hope to contribute to incorporation of community involvement, personal responsibility and self help in the changes needed in the Cuban health system.

\section{DEVELOPMENT}

The right to health, community engagement and personal responsibility WHO's constitution espouses the right of every human being to "the highest attainable standard of health."[5] This implies that states have an obligation to employ social mechanisms to guarantee enjoyment of this right. States have three types of obligations in this regard: to respect the right to health and refrain from interfering with it; to protect the right to health by preventing third parties from interfering with it; and to fulfill the right to health through appropriate regulatory and policy measures.[6]

In 2008, WHO's Commission on Social Determinants of Health[7] stressed the importance of reclaiming the premises and principles of the Alma Ata Declaration, which explicitly champions a vision of health as socially determined and calls for promotion of "maximum community and individual self-reliance and participation in the planning, organization, operation and control of primary health care... and to this end developing, through appropriate education, the ability of communities to participate."[8]

Since health is a social good, its conservation is not achieved solely by implementation of a centralized regulatory system of legislated health guidelines. Good governance in health is needed, translated into the state's political will and action at all levels to promote the population's greatest possible wellbeing, through development of comprehensive models that include health services, healthy public policies, community participation and intersectoral action.

And, since health is a human right, its care and protection is a shared responsibility among all. While the state has the primary obligation to ensure availability and equitable access to quality health services and also to promote other rights related to enjoyment of the highest possible level of wellbeing; individuals, families and communities together should recognize the moral obligation to respond to the state's actions with an attitude that recognizes their own responsibility, ethically supported in assuming beneficence as responsibility and justice as solidarity in line with the principle of shared responsibility.[9]

Citizen responsibility and Cuba's health system reform Our Constitution upholds the right of all Cubans to health care and protection.[10] The state's obligations in health care are fulfilled through public health legislation that establishes the basic principles of the national health system (NHS): state responsibility for and social nature of medicine; free and accessible health services; a disease prevention and health promotion orientation; appropriate application of scientific and technological advances; and community involvement.[11] 
Health indicators in Cuba over the past 53 years attest to the priority given the right to health by the state and to its efforts to fulfill its related obligations.[12,13] Cuban and international authors have concluded that Cuba's population health status is the result of political will to make health a human right for all citizens.[14-16]

These achievements have been possible thanks in part to various forms of community engagement in health promotion and disease prevention activities adopted at the macrosocial level over the past five decades, combining a tradition of community participation with express intersectoral action for population health and quality of life.[16] But intersectorality and social participation did not emerge spontaneously; they had to be adapted conceptually to Cuba's health system, supported by political will, and designed technically in such a way as to ensure their natural incorporation.[17]

Cuba's experience in social cohesion, intersectoral action and community participation in health has placed it in a privileged position, even though the degree of community engagement has not been entirely as desired. Some authors suggest that such involvement has been more highly developed in its collaborative or joint management forms without extending to higher forms such as self management or negotiated participation.[18,19] As a result, often the public only collaborates when asked or simply participates through representatives at various jurisdictional levels of governmental structures: electoral districts and their corresponding popular councils; municipal and provincial assemblies; and the national parliament.

It is essential that we reach higher forms of participation such as self management and negotiated participation, which are more closely aligned to the logic of personal responsibility and comprise a spectrum of actions performed by individuals, alone or with family assistance, aimed at improving or solving their health problems and needs.[19] Achieving the systematic, timely and high-quality community engagement required by current population health status and its determinants is and will remain a challenge for the national health system and government, since local conditions vary considerably.

Several programmatic documents have been developed in the past decade directed at improving population health in Cuba. One of them, a strategy paper, Public Health Projections for 2015 in Cuba, emphasizes the need to strengthen mechanisms for community engagement for population health promotion and disease prevention.[20] In 2011, health sector workers and leaders discussed the document, Transformations Needed in the Public Health System,[21] which sets out the Cuban state's commitment and will to preserve and improve health outcomes as well as to address new challenges generated by Cuba's population health and economic situation. Service reorganization, consolidation and regionalization are the main actions contemplated.

Although community involvement, personal responsibility and self help are not explicitly mentioned in the latter document, they undoubtedly represent key factors that should be revitalized and inserted into the health sector reform process. This implies not only actions that the community should take for its own health, but also self care at the individual level, consisting of appropriate use of health services and other activities directly or indirectly intended to support healthy living.
Engagement and personal responsibility in managing the most important chronic non-communicable diseases (NCD) According to $\mathrm{WHO}$, millions of premature deaths could be averted and world population life expectancy increased if efforts were targeted at combating the common risk factors for four groups of NCDs: cardiovascular diseases, cancers, chronic respiratory diseases and diabetes mellitus.[22] This is true for Cuba as well. At the end of 2011, these NCDs were among the top ten causes of death, occupying the first, second, sixth and eighth places respectively. [12] Preliminary data from the Third National Survey on Risk Factors and Chronic Diseases provide evidence of increased population prevalence of physical inactivity (45\%) and high blood pressure (30.9\%). Smoking prevalence (30.8\%) is still higher than desired, despite a decrease since earlier surveys.[20,23]

Prevention is recognized as the cornerstone of the global response to NCDs, since they are associated with a complex panorama of inter-related risk factors, causes and "causes of causes," in social contexts that are diverse and challenging. Reduction of individual and population exposure to common modifiable NCD risk factors is essential; concurrently, we must strengthen the capacity of individuals and populations to exercise personal responsibility in choosing healthier alternatives and adopting healthier lifestyles.[22]

Developing preventive psychosocial actions in health is meant to encourage healthy behaviors and attitudes, but these actions have not yet reached their full potential in the Cuban health system's policies and strategies. For decades, health professionals have been charged with health promotion and disease prevention actions, while the population, rather than taking on the role of a true "participant subject," has remained in a state of anonymous collaboration in decisionmaking, demanding essential functions of cure and rehabilitation from the health sector but not promotion and prevention.[24]

The population's passive role and predominance of the state in health actions have left health care almost entirely in the hands of service providers. This is illustrated in public health legislation itself[11] and its accompanying regulations; these establish duties and rights in relation to health, but recognize the population only as service users or beneficiaries, rather than as agents of their individual and collective health. This situation that assumes the health system and its services as the only decisionmakersboth for implementing preventive actions and setting priorities for offering health services-restricts development of healthy public policies in which citizens are considered individual and collective subjects who daily generate their own norms, habits and culture and transmit these from one generation to another. Further, no description is given of self-care actions citizens should take for personal and collective health, sidestepping the personal responsibility that facilitates community involvement.

In these times of needed reform, we must renew the concept of personal responsibility as the basis for community involvement, and include explicit and permanent strategies to develop both in Cuba's national public health system. This certainly could contribute to-among other things-lower mortality rates from NCDs, by promoting and developing healthy behaviors.

Given the prevailing paternalism and medical hegemony, how to do this remains a challenge, but there are some actions that 


\section{Perspective}

could help set us on the road to transforming health services and the community and efficiently raising Cuba's levels of population health and wellbeing. In particular, we suggest steps be taken to:

- summarize the best experiences (and also the negative lessons) in Cuba and globally;

- review existing theoretical models of behavioral change, adapting them to Cuban needs and conditions;

- generalize results of health and social research on personal responsibility as the basis for participation by individuals, families and groups in their neighborhoods, workplaces or schools (a research topic that should be prioritized by the Ministry of Public Health and the Cuban Academy of Sciences, to find common factors that allow us to take action in and with the community, with the civic duty to contribute to health as a point of departure);

- assume the risks of techniques to encourage active social participation, with the concomitant responsibility, as we do when we balance benefits and risks in using a medication for a sick individual; and

- properly analyze costs and potential benefits of alternative policies and interventions.

\section{CONCLUSIONS}

Cuba's current health problems demand greater and more consistent engagement by communities and social networks-family and friends; cultural, scientific, religious and civic organizations; etc.-in health care and its management, as well as in generating health-seeking behaviors to improve population health status. This can be accomplished through actions that should be an integral part of the intersectoral process of transforming public health, stemming from a logic of duties as well as rights.

In a society such as Cuba's, with a political system characterized by high levels of social organization and cohesion and where humanism and solidarity are declared core values, objective and subjective conditions exist for reversing a certain public inertia in relation to caring for people's health and that of their families, neighbors, co-workers, friends and community in general.

Health system reforms currently under way need the contribution citize can make through their personal responsibility for the care and protection of individual and collective health, through public mechanisms of empowerment that assure the sustainability of healthy public policies, intersectoral action and social protection of health, based on the principle of shared responsibility.

The population in fact should be an integral part of public health's intersectoral process, not only in the role of service recipients (users with rights), but also as active agents (actors with duties) in achieving better health for all. We believe that this contribution by citizens will, along with other factors, result in greater effectiveness and efficiency of all actions undertaken to improve Cuban population health. $-1 /$ -

\section{References}

1. Palma-Solís MA, Franco Giraldo A, Álvarez-Dardet C. Influencias y hegemonías en la orientación de la investigación de las reformas de salud. Cad Saúde Pública. 2006;22(12):2527-37. Spanish.

2. Jiménez Cangas L, Báez Dueñas RM, Pérez Maza B, Reyes Álvarez I. Metodología para la evaluación de la calidad en instituciones de atención primaria de salud. Rev Cubana Salud Pública [Internet]. 1996 [cited 2012 Mar 29];22(1):15-6. Available from: http://scielo.sld .cu/scielo. php?script=sci_arttext\&pid=S0864 $-34661996000100008 \&$ Ing=es. Spanish.

3. Martínez Calvo S. Valoración epidemiológica de las actividades de atención primaria de salud. Rev Cubana Med Gen Integr [Internet]. 2003 [cited 2012 Mar 29];19(1). Available from: http://scielo .sld.cu/scielo.php?script=sci_arttext\&pid=S0864 $-21252003000100011 \&$ lng=es. Spanish.

4. Arenas Monreal L, Jasso Arenas J, Campos Navarro R. Autocuidado: elementos para sus bases conceptuales. Global Health Promotion [Internet]. 2011;18(4):42-8. Available from: http:// ped.sagepub.com/content/18/4/42. Spanish.

5. Documentos básicos. Carta fundacional de la OMS [Internet]. Geneva: World Health Organization; 2006 Oct [cited 2012 Mar 29]. 20 p. Available from: http://www.who.int/governance/eb/ who_constitution_sp.pdf. Spanish.

6. The Right to Health. Fact Sheet No. 31 [Internet]. Geneva: World Health Organization and Office of the United Nations High Commissioner for Human Rights; 2008 Jun [cited 2012 Mar 29]. 52 p. Available from: http://www.unhcr.org/refworld/category, REFERENCE,OHCHR,,,48625a742,0.html

7. Comisión sobre Determinantes Sociales de la Salud. Resumen analítico del informe final [Internet]. Geneva: World Health Organization; 2008 [cited 2012 Mar 29]. 40 p. Available from: http://whqlibdoc.who.int/hq/2008/WHO_IER _CSDH_08.1_spa.pdf. Spanish.

8. World Health Organization [Internet]. Geneva: World Health Organization; c2012 Documentos básicos. Declaración de Alma Ata; 1978 Sep [cited 2012 Mar 29]; [about 2 screens]. Available from: http://www.paho.org/spanish/dd/pin/alma -ata_declaracion.htm. Spanish.

9. Acosta Sariego JR. Responsabilidad y solidaridad en las relaciones sanitarias en Cuba. Rev Cubana de Salud Pública [Internet]. 2006 [cited 2011 Dec 8];32(4). Available from: http://scielo .sld.cu/scielo.php?script=sci_issuetoc $\&$ pid $=0864$ -346620060004\&lng=es\&nrm=iso. Spanish.

10. Constitución de la República de Cuba [Internet] 2002 Jun [cited 2011 Sep 25]. Available from: http://www.gacetaoficial.cu/html/constitucion _de_la_republica.html\#cap4. Spanish.

11. National Assembly of Peoples Power (CU). Ley No. 41 de Salud Pública; 1983 Aug 15. Spanish.

12. Anuario Estadístico de Salud 2010 [Internet] Havana: Ministry of Public Health (CU); 2011[cited 2012 Mar 29]. Available from: http://files.sld .cu/dne/files/2012/04/anuario-2011-e.pdf. Spanish.

13. Keck CW, Reed GA. The Curious Case of Cuba Am J Public Health. 2012 Aug;102(8):e13-22.

14. Álvarez Pérez AG, García Fariñas A, Bonet Gorbea $\mathrm{MH}$. Pautas conceptuales y metodológicas para explicar los determinantes de los niveles de salud en Cuba. Rev Cubana Salud Pública [Internet]. 2007 [cited 2011 Sep 25];33(2). Available from: http://www.bvs.sld.cu/revistas/spu/ vol33_02_07/spu13207.htm. Spanish.

15. Álvarez $\overline{A G}$, García A, Rodríguez A, Bonet M. Voluntad política y acción intersectorial: Premisas clave para la determinación social de la salud en Cuba. Rev Cubana Hig Epidemiol [Internet]. 2007 Dec [cited 2010 Nov 14];45(3):116. Available from: http://scielo.sld.cu/pdf/hie/ v45n3/hie07307.pdf. Spanish.

16. Pagliccia N, Alvarez Pérez A. The Cuban Experience in Public Health: Does Political Will Have a Role? Int J Health Services [Internet]. 2012 [cited 2012 Mar 29];42(1):77-94. Available from: http:// baywood.metapress.com/app/home/contribu tion.asp?referrer=parent\&backto=issue, 8,$13 ;$;ou rnal,2,166; linkingpublicationresults,1:300313,1

17. Castell-Florit P. La intersectorialidad, una tecnología que despega con fuerza. Rev Cubana Salud Pública [Internet]. 2010 Jun [cited 2012 Sep 20];36(2):101. Available from: http://scielo .sld.cu/scielo.php?script=sci_arttext\&pid=S0864 $-34662010000200001 \& \operatorname{lng}=\bar{e}$. Spanish.

18. Romeo Cepero D V. Capacidad comunitaria en beneficio de promover salud en la colectividad. Rev Cubana Med Gen Integr [Internet]. 2007 [cited 2012 Mar 29];23(3). Available from: http://scielo .sld.cu/scielo.php?script=sci_arttext \&pid=S0864-21252007000300013\&lng=es . Spanish.

19. Sanabria Ramos G. Participación Social en el campo de la salud. Rev Cubana de Salud Pública [Internet]. 2004 [cited 2012 Sep 25];30(3):214-24. Available from: http://scielo.sld.cu/scielo.php?pid=S0864 $-34662004000300005 \&$ script=sci_arttext\&tlng =es. Spanish.

20. Ministry of Public Health (CU). Proyecciones de la salud Púbica en Cuba para el 2015. Havana: Editorial de Ciencias Médicas; 2006 Feb. Spanish.

21. Transformaciones necesarias en el sistema de salud pública [Internet]. Havana: Ministry of Public Health (CU); 2010 Nov [cited 2011 Sep 25]. Available from: http://files.sld.cu/editorhome/ files/2010/11/transformaciones-necesarias -salud-publica.pdf. Spanish.

22. Declaración Política de la Reunión de Alto Nivel de la Asamblea General sobre la Prevención y el Control de las Enfermedades No Trasmisibles. Geneva: World Health Organization; 2011 Sep 16. Spanish.

23. Reed G. New Survey Results Enhance Cuba's NCD Surveillance: Mariano Bonet Director, National Hygiene, Epidemiology and Microbiology Institute. MEDICC Rev [Internet]. 2011[cited 2011 Jun 25];13(4):11-3. Available from: http://www .scielosp.org/scielo.php?pid=S1555-796020 $11000400004 \&$ script=sci_arttext 
24. Rodríguez Méndez M, Echemendía Tocabens B La prevención en salud: posibilidad y realidad. Rev Cubana de Higiene y Epidemiología [Internet]. 2011 [cited 2012 Mar 29];49(1):135-50. Available from: http://scielo.sld.cu/pdf/hie/v49n1/ hie15111.pdf

\section{AUTHORS}

Isabel P. Luis Gonzálvez (Corresponding author: isapi@inhem.sld.cu; isabelpl@infomed. sld.cu), physician with specialties in public health and epidemiology and a master's degree in bioethics. Instructor, National Hygiene, Epidemiology and Microbiology Institute (INHEM), Havana, Cuba.

Silvia Martínez Calvo, physician specializing in public health. Distinguished professor and researcher, National School of Public Health, Havana, Cuba.
Adolfo Alvarez Pérez, biologist specializing in global public health. Associate professor and researcher, INHEM, Havana, Cuba.

Submitted: December 24, 2011

Approved for publication: August 23, 2012

Disclosures: None 